\title{
Assessment of Health-Related Quality of Life in Pediatric Acute Lymphoblastic Leukemia Survivors: Perceptions of Children, Siblings, and Parents
}

\author{
Çocukluk Çağı Akut Lenfoblastik Lösemi Sağ Kalanlarında Sağlıkla Illişkili Yaşam Kalitesinin \\ Değerlendirilmesi: Çocukların, Kardeşlerin, Ebeveynlerin Algılaması
}

(D) Deniz Kızmazoğlu1, (D) Seher Sarı1, (D) Melike Evim Sezgin2, (D) Arzu Kantarcıoğlu², (D) Özlem Tüfekçi1, (D) Fatma Demir Yenigürbüz1, (D) Birol Baytan2, (D) Şebnem Yılmaz'1, (D) Adalet Meral Güneş², (D) Hale Ören¹

${ }^{1}$ Dokuz Eylül University Faculty of Medicine, Department of Pediatric Hematology, Izmir, Turkey

2Uludağ University Faculty of Medicine, Department of Pediatric Hematology, Bursa, Turkey

\section{Abstract}

Objective: We investigated the health-related quality of life (HROL) in survivors of pediatric acute lymphoblastic leukemia (ALL) and evaluated the perceptions of the children, their siblings, and their parents.

Materials and Methods: Seventy ALL survivors, who were between 7 and 17 years of age and had completed therapy $\geq 2$ years, were included. The control group consisted of their healthy siblings. HROL was assessed by the age-specific KINDLR questionnaire.

Results: No significant differences could be found among HROL scores of ALL survivors with respect to variables such as sex, risk group, and having chronic illness. HRQL scores for physical well-being, emotional well-being, family, and social functioning of the patient and sibling self-reports and parent proxy reports were lower than the expected values for healthy and chronically ill children.

Conclusion: These results demonstrate that both ALL survivors and their families need help via psychological counseling programs to improve their HROL even after completion of therapy.

Keywords: Acute lymphoblastic leukemia, Health-related quality of life, KINDLR questionnaire

\section{Introduction}

Acute lymphoblastic leukemia (ALL) comprises 26\%-28\% of all childhood malignancies $[1,2]$. The outcome of ALL has improved and survival periods have become longer $[3,4]$. Five-year overall survival was 79.9\% at our centers between 1995 and 2009 [5]. Investigations of survivors have documented that their quality
Öz

Amaç: Çocukluk çağı akut lenfoblastik lösemi (ALL) sağ kalanlarında sağlıkla ilişkili yaşam kalitesinin (HROL) araştırılması ve çocukların, kardeşlerinin ve ebeveynlerinin bununla ilgili algılamalarının değerlendirilmesi amaçlandı.

Gereç ve Yöntemler: Çalışma grubu 7-17 yaş arası, kemoterapisi en az 2 yıl önce tamamlanmış 70 ALL'li çocuktan oluşturuldu. Kontrol grubu hastaların sağlıklı kardeşlerini $(n=32)$ içerdi. HROL ölçümü için yaşa uygun $\mathrm{KINDL}^{\mathrm{R}}$ anket formları kullanıldı.

Bulgular: ALL sağ kalanlarında HROL skorları cinsiyet, risk grubu, kronik hastalığı olma ve relaps öyküsü açısından istatistiksel anlamlı fark göstermedi. Hastalar ve kardeşlerinin HROL skorlarıyla ebeveynlerin hasta çocuklarının durumuna bakış açısı skorları değerlendirildiğinde fiziksel iyilik, duygusal iyilik, aile ve sosyal ilişkiler ile ilgili HROL skorları sağlıklı ve kronik hastalığa sahip çocuklara göre düşük bulundu.

Sonuç: Hasta ve ebeveynlerin HRQL skorlarının düşük saptanması çocukluk çağı ALL sağ kalanları ve ebeveynlerinin tedavi bitimi sonrasında da psikolojik danışmanlık programlarına ihtiyacı olduğunu göstermektedir.

Anahtar Sözcükler: Akut lenfoblastik lösemi, Sağlıkla ilişkili yaşam kalitesi, KINDLR anketi intellectual functioning $[6,7,8,9,10]$.

The aim of this study was to investigate health-related quality of life (HROL) in survivors of pediatric ALL and to evaluate the perceptions of the children, their siblings, and their parents. 


\section{Materials and Methods}

\section{Patients}

The study population consisted of children who were diagnosed with ALL and had been treated with the ALL Berlin-FrankfurtMuenster (BFM) 95 protocol [11] at Dokuz Eylül University and Uludağ University Hospitals. We included 70 children diagnosed with ALL who were between the ages of 7 and 17 years, in complete remission, who had been followed for $\geq 2$ years after completion of therapy. The control group consisted of 32 healthy siblings. We analyzed only one sibling of a patient who was in the age group of 7-17 years to obtain reliable results, since children may begin adequately describing their HROL by the age of 7 years [12]. One parent for each patient (62 mothers, 8 fathers) filled out a questionnaire.

The sociodemographic data of the patients were collected via questionnaire. Data about ALL therapy and follow-up period were recorded from hospital files. If the family's monthly income was under 2000 Turkish lira (TL), participants were classified in the lower income group; if it was between 2000 and $5000 \mathrm{TL}$, they were classified in the middle income group; and if it was above $5000 \mathrm{TL}$, they were classified in the higher income group.

\section{Evaluation of HRQL}

There are different methods for evaluating HRQL $[12,13,14,15,16]$. We used the $\operatorname{KINDL}^{\mathrm{R}}$ questionnaire for measuring $\mathrm{HROL}$ in children and adolescents. The KINDLR questionnaire was developed by Bullinger et al. and revised by Ravens-Sieberer and Bullinger $[13,14,15,16,17]$. The KINDLR aims more at the psychosocial than the physical aspects of HROL. The method of assessment is child self-report or parent proxy report. Age- and sex-specific versions take into account the changes in the HROL dimensions in the course of child development $[14,15,17]$. The KINDLR questionnaire consists of 24 items that assess six subscales: physical wellbeing, emotional well-being, self-esteem, family, friends, and everyday functioning (school) [17]. A total score of these six subscales is calculated after transforming the raw data on a scale ranging from 0 to 100 . The Turkish version of the KINDLR questionnaire was modified by Eser et al. [18] and the results of their study indicated that the Turkish Kid-KINDL is a reliable and factorially valid assessment of children's HROL.

\section{Statistical Analysis}

The data were evaluated using SPSS 20.0 for Windows. Comparing the categorical variables of groups, nonparametric Kruskal-Wallis analysis was used. The Student t-test and MannWhitney $U$ test were used when appropriate. Correlation and regression were used for determining the relationship between quality of life scores. Correlation was calculated with the Pearson correlation as a parametric method, while Spearman rank correlations (categorical variables) were calculated to evaluate relationships between changes in HROL scores.

This study was approved by the Ethics Committee of the Dokuz Eylül University Faculty of Medicine (approval number: 2015/1011).

\section{Results}

The mean age of patients at the time of the study was $12.7 \pm 2.5$ years and the mean age at diagnosis was $4.8 \pm 2.4$ years. Fortytwo patients $(60 \%)$ were in the age group of 7-13 years and 28 patients (40\%) were in the age group of 14-17 years. The study group represented $65 \%$ of the survivors treated at two centers with similar characteristics. The sociodemographic properties of the study group are given in Table 1. Median follow-up duration was 8.2 years after completion of chemotherapy (Table 2). The mean age of the siblings was $14.1 \pm 2.9$ years. There was statistically no difference between the two groups in age or sex. Information about the treatment center, therapy type, risk group of patients, relapse history, and time after therapy is summarized in Table 2.

Twelve patients (17.1\%) had chronic disease. Seven of them had endocrinological disease (obesity, insulin resistance, hypothyroidism), 4 had cardiac disease (2 hypertension, 2 minimal diastolic dysfunction), and 1 had epilepsy.

Statistically, no differences could be found among HROL scores of survivors with respect to variables including sex, therapy type, risk group, time after completion of therapy, income status, having chronic illness, relapse history, and therapy center.

The mean HROL scores of patients, siblings, and healthy and chronically ill children (children with chronic diseases such as asthma, obesity, and neurodermatitis) from self-reports and parent proxy reports are given in Table $3[14,15,17]$. There were statistically no differences between the scores of patient selfreports, sibling self-reports, and parent proxy reports. Total HROL scores and the HROL scores for physical well-being,

\begin{tabular}{|l|l|l|l|l|}
\hline \multicolumn{5}{|c|}{ Table 1. Sociodemographic data of the patients. } \\
\hline \multirow{3}{*}{ Sex } & Patients & $\mathbf{n = 7 0}$ & $\%$ & \\
\hline \multirow{4}{*}{ Education year } & Female & 38 & 54 & \multirow{2}{*}{ ( } \\
& Male & 32 & 46 & \\
\hline \multirow{2}{*}{ Employment status } & No school & 1 & 1.4 & \\
& $1-5$ years & 27 & 38.6 & \\
\hline \multirow{2}{*}{ Household economic } & $6-10$ years & 37 & 52.9 & \\
condition & $>10$ years & 5 & 7.1 & \\
& Yes & 1 & 1.4 & \\
& No & 69 & 98.6 & \\
\hline & Middle income & 43 & 61.4 & \\
& High income & 20 & 28.6 & \\
\hline
\end{tabular}


emotional well-being, family, and social functioning of the patients and sibling self-reports and parent proxy reports were lower than the expected values for healthy and chronically ill children. The HROL scores for everyday functioning (school) of the patients appeared to be lower than the expected values for healthy children.

When we investigated the HROL scores of patient self-reports and sibling self-reports, we found no significant correlations between the two groups (physical well-being: $r=0.266, p=0.245$; emotional well-being: $r=0.264, p=0.275$; self-esteem: $r=-0.159$, $p=0.503$; friends: $r=0.122, p=0.609$; school: $r=-0.016, p=0.948$; family: $r=0.354, p=0.125$; and total score: $r=0.312, p=0.136$ ). When we investigated the HRQL scores of patient self-reports and parent proxy reports, we found moderate but significant

\begin{tabular}{|c|c|c|c|}
\hline \multicolumn{4}{|c|}{$\begin{array}{l}\text { Table 2. Information about patients' treatment center, } \\
\text { therapy type, risk group, relapse history, and time after } \\
\text { completion of therapy. }\end{array}$} \\
\hline & Patients & $\mathbf{n}$ & $\%$ \\
\hline \multirow[t]{2}{*}{ Treatment center } & $\begin{array}{l}\text { Dokuz Eylül } \\
\text { University }\end{array}$ & 51 & 72.9 \\
\hline & Uludağ University & 19 & 27.1 \\
\hline \multirow{3}{*}{ Therapy } & Only CT & 49 & 70.0 \\
\hline & $\mathrm{CT}+\mathrm{RT}$ & 16 & 22.9 \\
\hline & $\mathrm{CT}+\mathrm{HSCT}$ & 5 & 7.1 \\
\hline \multirow{3}{*}{ Risk group } & Standard risk & 10 & 14.3 \\
\hline & Intermediate risk & 47 & 67.1 \\
\hline & High risk & 13 & 18.6 \\
\hline \multirow{2}{*}{ Relapse } & Yes & 6 & 8.6 \\
\hline & No & 64 & 91.4 \\
\hline \multirow{2}{*}{ Site of relapse } & Bone marrow & 5 & 83.3 \\
\hline & Bone marrow + CNS & 1 & 16.7 \\
\hline \multirow{3}{*}{$\begin{array}{l}\text { Time after } \\
\text { completion of } \\
\text { therapy }\end{array}$} & $2-5$ years & 13 & 18.6 \\
\hline & $6-10$ years & 39 & 55.8 \\
\hline & $\geq 10$ years & 18 & 25.7 \\
\hline \multicolumn{4}{|c|}{$\begin{array}{l}\text { CT: Chemotherapy, RT: radiotherapy, HSCT: hematopoietic stem cell therapy, } \\
\text { CNS: central nervous system. }\end{array}$} \\
\hline
\end{tabular}

positive correlations for all subscales (physical well-being: $r=0.444, p=0.000$; emotional well-being: $r=0.331, p=0.005$; self-esteem: $r=0.244, p=0.042$; friends: $r=0.266, p=0.026$; school: $r=0.344, p=0.004$; family: $r=0.269, p=0.024$; and total score: $r=0.258, p=0.032$ ).

\section{Discussion}

Quality of life is negatively affected by the adverse effects of treatment in survivors of childhood leukemia $[19,20,21]$. In this study, we found no differences among HRQL subscale scores of ALL survivors with respect to variables including sex, therapy type, risk group, time after therapy, income status, having chronic illness, relapse history, and therapy center. Most of our patients were followed for more than 6 years after completion of therapy. A recent review of 22 studies representing 2073 children found that overall HROL is reduced among children with $A L L$ receiving treatment compared to healthy children, and HRQL was reported to improve over time after completion of therapy [20]. In the same review, inconsistent associations between clinical/demographic factors and HROL outcomes were found; poor HRQL during ALL treatment appeared to be associated with intensive phases of chemotherapy, experiencing greater toxicity, corticosteroid therapy, older age, and female sex. High-risk patients who have undergone hematopoietic stem cell therapy may have poorer HROL scores. In a recent study, it was demonstrated that HROL and depression scores were significantly lower among survivors 2-5 years after treatment when compared to 6-10 years and 10 years or more [21]. Similar to our findings, Kanellopoulos et al. [19] and Sitaresmi et al. [22] reported that demographic characteristics, cancer, and treatment-related variables were not associated with poor HROL in survivors. Identifying children at higher risk of these side effects and determining effective supportive care can improve HRQL outcomes [19,20,23,24].

Evaluation of HRQL in children is not easy $[12,25,26]$. Patients who were 7-17 years old were included in this study to obtain reliable results and appropriate $\mathrm{KINDL}^{\mathrm{R}}$ questionnaires were

\begin{tabular}{|c|c|c|c|c|c|c|}
\hline \multirow[t]{2}{*}{ Subscale } & \multirow{2}{*}{$\begin{array}{l}\text { Patients, } \\
\text { mean } \pm \text { SD }\end{array}$} & \multirow{2}{*}{$\begin{array}{l}\text { Siblings, } \\
\text { mean } \pm \text { SD }\end{array}$} & \multirow{2}{*}{$\begin{array}{l}\text { Parents, } \\
\text { mean } \pm \text { SD }\end{array}$} & \multirow{2}{*}{$\begin{array}{l}\text { Healthy } \\
\text { children* }\end{array}$} & \multicolumn{2}{|c|}{ Chronically ill children** } \\
\hline & & & & & Children & Parents \\
\hline Emotional well-being & $36.69 \pm 13.15$ & $34.21 \pm 13.20$ & $35.53 \pm 14.80$ & 83.01 & $80.31 \pm 14.88$ & $69.44 \pm 17.75$ \\
\hline Self-esteem & $63.66 \pm 23.60$ & $64.06 \pm 22.10$ & $69.82 \pm 22.40$ & 66.60 & $57.88 \pm 20.56$ & $56.06 \pm 19.50$ \\
\hline School & $63.03 \pm 15.41$ & $71.87 \pm 20.20$ & $60.98 \pm 15.90$ & 73.13 & $64.56 \pm 21.88$ & $66.63 \pm 18.06$ \\
\hline Total score & $54.06 \pm 7.40$ & $54.00 \pm 16.43$ & $54.31 \pm 14.79$ & 76.75 & $70.58 \pm 11.94$ & $56.58 \pm 13.15$ \\
\hline
\end{tabular}


used for child self-reports and parent proxy reports $[14,15,17]$. We found that total HROL scores of the ALL survivors appeared to be lower than the expected values for healthy and chronically ill children in the literature $[14,15,17]$. A strong association between poor HRQL in survivors of pediatric ALL and depression, anxiety, insomnia, pain, and obesity was found in several studies $[19,20,21,27,28,29,30]$. As a remarkable finding of our study, the scores for physical well-being, emotional well-being, family, and social functioning of the patient and sibling self-reports and parent proxy reports also appeared to be lower than the expected values for healthy and chronically ill child self-reports and their parent proxy reports. Including siblings and healthy children for two different control groups would make our study results stronger. As a control group, we could have chosen healthy children, but their family functioning and sociocultural situations could show differences. The reduced HROL scores for these subscales may be due to problematic family functioning, household size, or social and cultural impairment $[19,30]$. The diagnosis, treatment, and follow-up periods for ALL cause significant disruption to normal family life and this negative effect may continue for many years $[19,20,21]$.

In our study the HROL scores of patient self-reports and parent proxy reports showed moderate but significant positive correlations in all subscales. It has been established that parent perception is important and ideally should reflect the child self-report $[31,32,33]$. The parent's perception may not always be consistent with the child's self-report, with parents overestimating their children's impairment $[20,34,35,36]$. Mothers were more likely to report better HROL in their children than fathers during induction therapy for ALL [37]. Children who self-reported poorer quality of life had mothers who were more depressed; parents who reported poorer quality of life for their children reported more illness stressors and perceived their children as being more vulnerable [36]. Exploration of the reasons for differences may improve the parent-child relationship.

\section{Conclusion}

The low HROL scores of the patient and sibling self-reports and parent proxy reports showed that both ALL survivors and their families need help via psychological counseling programs. Identifying patients and families at risk and providing them psychological support may improve the HROL for ALL survivors and their families.

\section{Acknowledgments}

The authors would like to thank all the children and parents who participated in the study. They acknowledge the support of Dr. Pembe Keskinoğlu, Department of Biostatics and Medical Informatics, Dokuz Eylül University, and her valuable input on the statistical analysis of this report.

\section{Ethics}

Ethics Committee Approval: This study was approved by the Ethics Committee of the Dokuz Eylül University Faculty of Medicine (approval number: 2015/10-11).

Informed Consent: It was obtained from parents or legal guardians before patients' enrollment in the study.

\section{Authorship Contributions}

Concept: S.S., A.M.G., H.Ö.; Design: S.S., A.M.G., Ş.Y., H.Ö.; Data Collection or Processing: S.S., D.K., M.E.S., A.K., B.B., F.D.Y., Ş.Y.; Analysis or Interpretation: S.S., D.K., Ö.T., A.M.G., H.Ö.; Literature Search: S.S., D.K., Ö.T., H.Ö.; Writing: D.K., Ö.T., H.Ö.

Conflict of Interest: The authors of this paper have no conflicts of interest, including specific financial interests, relationships, and/or affiliations relevant to the subject matter or materials included.

\section{References}

1. Linabery $\mathrm{AM}$, Ross JA. Trends in childhood cancer incidence in the US (1992-2004). Cancer 2008;112:416-432.

2. Spallek J, Spix C, Zeeb H, Kaatsch P, Razum O. Cancer patterns among children of Turkish descent in Germany: a study at the German Childhood Cancer Registry. BMC Public Health 2008;8:152.

3. Schrappe M, Möricke A, Reiter A, Henze G, Welte K, Gadner H, Ludwig WD, Ritter J, Harbott J, Mann G, Klingebiel T, Gruhn B, Niemeyer C, Kremens B, Niggli F, Debatin KM, Ratei R, Stanulla M, Beier R, Cario G, Schrauder A, Zimmermann M. Key treatment questions in childhood acute lymphoblastic leukemia: results in 5 consecutive trials performed by the ALL-BFM study group from 1981 to 2000. Klin Padiatr 2013;225(Suppl 1):62-72.

4. Schrappe M, Nachman J, Hunger S, Schmiegelow K, Conter V, Masera G, Pieters $\mathrm{R}$, Pui $\mathrm{CH}$. Educational symposium on long-term results of large prospective clinical trials for childhood acute lymphoblastic leukemia (1985-2000). Leukemia 2010;24:253-254.

5. Güneş AM, Ören $H$, Baytan B, Bengoa SY, Evim MS, Gözmen S, Tüfekçi 0, Karapınar $\mathrm{TH}$, İken G. The long-term results of childhood acute lymphoblastic leukemia at two centers from Turkey: 15 years of experience with the ALL-BFM 95 protocol. Ann Hematol 2014;93:1677-1684.

6. Pui CH, Yang JJ, Hunger SP, Pieters R, Schrappe M, Biondi A, Vora A, Baruchel A, Silverman LB, Schmiegelow K, Escherich G, Horibe K, Benoit YC, Izraeli $S$, Yeoh AE, Liang DC, Downing JR, Evans WE, Relling MV, Mullighan CG. Childhood acute lymphoblastic leukemia: progress through collaboration. J Clin Oncol 2015;33:2938-2948.

7. Mody R, Li S, Dover DC, Sallan S, Leisenring W, Oeffinger KC, Yasui Y, Robison LL, Neglia JP. Twenty-five-year follow-up among survivors of childhood acute lymphoblastic leukemia: a report from the childhood cancer survivor study. Blood 2008;111:5515-5523.

8. Robison LL. Late effects of acute lymphoblastic leukemia therapy in patients diagnosed at 0-20 years of age. Hematology Am Soc Hematol Educ Program $2011 ; 2011: 238-242$

9. Haddy TB, Mosher RB, Reaman GH. Late effects in long-term survivors after treatment for childhood acute leukemia. Clin Pediatr (Phila) 2009;48:601608.

10. Kalafatcilar Al, Tüfekçi $\mathrm{O}$, Ören $H_{,}, H_{ı}$ S, Güleryüz $H$, Akay A, Orçim E, Olgun Y, İren G. Assessment of neuropsychological late effects in survivors of childhood leukemia. Pediatr Hematol Oncol 2014;31:181-193. 
11. Möricke A, Reiter A, Zimmermann M, Gadner H, Stanulla M, Dördelmann M, Löning L, Beier R, Ludwig WD, Ratei R, Harbott J, Boos J, Mann G, Niggli F, Feldges $A$, Henze $G$, Welte $K$, Beck JD, Klingebiel $T$, Niemeyer $C$, Zintl $F$, Bode $U$, Urban $C$, Wehinger $H$, Niethammer $D$, Riehm $H$, Schrappe $M$; German-Austrian-Swiss ALL-BFM Study Group. Risk-adjusted therapy of acute lymphoblastic leukemia can decrease treatment burden and improve survival: treatment results of 2169 unselected pediatric and adolescent patients enrolled in the trial ALL-BFM 95. Blood 2008;111:4477-4489.

12. Savage $E$, Riordan $A 0$, Hughes $M$. Quality of life in children with acute lymphoblastic leukemia: a systematic review. Eur J Oncol Nurs 2009;13:36-48.

13. Bullinger M, Mackensen S, Kirchberger I. KINDL - ein Fragebogen zur gesundheitsbezogenen Lebensqualität von Kindern. Zeitschrift für Gesundheitspsychologie 1994;2:64-67.

14. Ravens-Sieberer U, Görtler E, Bullinger M. Subjective health and health behavior of children and adolescents--a survey of Hamburg students within the scope of school medical examination. Gesundheitswesen 2000;62:148-155.

15. Ravens-Sieberer U, Bullinger M. Assessing the health related quality of life in chronically ill children with the German KINDL: first psychometric and content-analytical results. Quality Life Res 1998:7:399-407.

16. Ravens-Sieberer U, Ellert U, Erhart M. Health related quality of life of children and adolescents in Germany. Norm data from the German Health Interview and Examination Survey (KiGGS). Bundesgesundheitsblatt Gesundheitsforschung Gesundheitsschutz 2007;50:810-818.

17. Ravens-Sieberer $U$, Bullinger M. KINDLER Questionnaire for Measuring Health-Related Quality of Life in Children and Adolescents, Revised Version. Manual 2000. Available online at https://www.kindl.org/english/manual/.

18. Eser $E_{1}$ Yüksel H, Baydur H, Erhart M, Saatli G, Cengiz Ozyurt B, Ozcan $\mathrm{C}$, Ravens-Sieberer U. The psychometric properties of the new Turkish generic HROL questionnaire for children (Kid-KINDL). Turk Psikiyatri Derg 2008;19:409-417.

19. Kanellopoulos A, Hamre HM, Dahl AA, Fosså SD, Ruud E. Factors associated with poor quality of life in survivors of childhood acute lymphoblastic leukemia and lymphoma. Pediatr Blood Cancer 2013;60:849-855.

20. Vetsch J, Wakefield CE, Robertson EG, Trahair TN, Mateos MK, Grootenhuis M, Marshall GM, Cohn RJ, Fardell JE. Health-related quality of life of survivors of childhood acute lymphoblastic leukemia: a systematic review. Qual Life Res 2018;27:1431-1443.

21. Baytan B, Aşut Ç, Çırpan Kantarcıoğlu A, Sezgin Evim M, Güneş AM. Health-related quality of life, depression, anxiety, and self-image in acute lymphocytic leukemia survivors. Turk J Hematol 2016;33:326-330.

22. Sitaresmi MN, Mostert S, Gundy CM, Sutaryo, Veerman AJ. HROL assessment in Indonesian childhood acute lymphoblastic leukemia. Health Qual Life Outcomes 2008;6:96.

23. Essig S, von der Weid NX, Strippoli MP, Rebholz CE, Michel G, Rueegg CS, Niggli FK, Kuehni CE; Swiss Pediatric Oncology Group (SPOG). HROL in longterm survivors of relapsed childhood acute lymphoblastic leukemia. PLoS One 2012;7:e38015.

24. Benadiba J, Michel G, Auquier $P$, Chastagner $P$, Kanold J, Poirée $M$, Plantaz D, Padovani L, Berbis J, Barlogis V, Contet A, Chambost H, Sirvent
N. Health status and quality of life of long-term survivors of childhood acute leukemia: the impact of central nervous system irradiation. J Pediatr Hematol Oncol 2015;37:109-116.

25. Pickard AS, Topfer LA, Feeny DH. A structured review of studies on health-related quality of life and economic evaluation in pediatric acute lymphoblastic leukemia. J Natl Cancer Inst Monogr 2004;33:102-125.

26. Ravens-Sieberer U, Redegeld M, Bullinger M. Quality of life after in-patient rehabilitation in children with obesity. Int J Obes Relat Metab Disord 2001;25(Suppl 1):63-65.

27. Nayiager T, Anderson L, Cranston A, Athale U, Barr RD. Health-related quality of life in long-term survivors of acute lymphoblastic leukemia in childhood and adolescence. Qual Life Res 2017;26:1371-1377.

28. Furlong W, Rae C, Feeny D, Gelber RD, Laverdiere C, Michon B, Silverman L, Sallan S, Barr R. Health-related quality of life among children with acute lymphoblastic leukemia. Pediatr Blood Cancer 2012;59:717-724.

29. Wilson CL, Stratton K, Leisenring WL, Oeffinger KC, Nathan PC, WasilewskiMasker K, Hudson MM, Castellino SM, Stovall M, Armstrong GT, Brinkman TM, Krull KR, Robison LL, Ness KK. Decline in physical activity level in the childhood cancer survivor study cohort. Cancer Epidemiol Biomarkers Prevention 2014;23:1619-1627.

30. Myers RM, Balsamo L, Lu X, Devidas M, Hunger SP, Carroll WL, Winick NJ, Maloney KW, Kadan-Lottick NS. A prospective study of anxiety, depression, and behavioral changes in the first year after a diagnosis of childhood acute lymphoblastic leukemia. Cancer 2014;120:1417-1425.

31. Mitchell HR, Lu X, Myers RM, Sung L, Balsamo LM, Carroll WL, Raetz E, Loh ML, Mattano LA Jr, Winick NJ, Devidas M, Hunger SP, Maloney K, Kadan-Lottick NS. Prospective, longitudinal assessment of quality of life in children from diagnosis to 3 months off treatment for standard risk acute lymphoblastic leukemia: results of Children's Oncology Group study AALL0331. Int J Cancer 2016;138:332-339.

32. Tremolada $M$, Bonichini $S$, Altoè $G$, Pillon $M$, Carli $M$, Weisner TS. Parental perceptions of HROL in children with leukemia in the second week after the diagnosis: a quantitative model. Support Care Cancer 2011;19:591-598.

33. Pöder U, Ljungman G, von Essen L. Parents' perceptions of their children's cancer-related symptoms during treatment: a prospective, longitudinal study. J Pain Symptom Manage 2010;40:661-670.

34. Gordijn MS, van Litsenburg RR, Gemke RJ, Huisman J, Bierings MB, Hoogerbrugge PM, Kaspers GJ. Sleep, fatigue, depression, and quality of life in survivors of childhood acute lymphoblastic leukemia. Pediatr Blood Cancer 2013;60:479-485.

35. Eiser C, Morse R. Can parents rate their child's health-related quality of life? Results of a systematic review. Qual Life Res 2001;10:347-357.

36. Vance $\mathrm{YH}$, Morse RC, Jenney ME, Eiser $\mathrm{C}$. Issues in measuring quality of life in childhood cancer: measures, proxies, and parental mental health. J Child Psychol Psychiatry 2001;42:661-667.

37. van Litsenburg RR, Huisman J, Pieters R, Verhaak C, Kaspers GJ, Gemke RJ. Determinants of quality of life during induction therapy in pediatric acute lymphoblastic leukemia. Support Care Cancer 2014;22:3235-3242. 